\title{
PROFIL MISKONSEPSI SISWA DALAM MATERI SISTEM EKSKRESI MELALUI PENUGASAN PETA KONSEP
}

\author{
Lesy Luzyawati, Halimatul Hidayah \\ Universitas Wiralodra, Jl. Ir. H. Djuanda KM 3 Indramayu \\ Email: lesy.luzyawati@unwir.ac.id
}

Citasi: Luzyawati, L., \& Hidayah., H. (2019). Profil Miskonsepsi Siswa Dalam Materi Sistem Ekskresi Melalui Penugasan Peta Konsep. Mangifera Edu volume 3 (2): $72-87$

\begin{abstract}
ABSTRAK
Miskonsepsi siswa dalam Mata Pelajaran Biologi disebabkan pada proses pembelajaran sebagian guru kurang memperhatikan konsep awal yang dimiliki siswa sehingga mereka sulit mempelajari konsep baru. Penelitian ini bertujuan untuk mengetahui profil miskonsepsi siswa kelas XI SMA Negeri 1 Sliyeg Indramayu pada materi sistem ekskresi melalui penugasan peta konsep. Jenis penelitian yang digunakan adalah metode kuantitatif deskriptif dan desain penelitiannya yaitu Pre-Experimental Designdengan bentuk One-shot Case Study. Populasi dalam penelitian ini adalah seluruh kelas XI MIPA SMA Negeri 1 Sliyeg Indramayu yang terdiri dari empat kelas dengan jumlah siswa 145 orang.Penelitian ini menggunakan teknik penarikan sampel Purposive Samplingdan diperoleh sampel yaitu kelas XI MIPA 4. Instrumen yang digunakan yaitu tes pilihan ganda beralasan disertai dengan CRI (Certainty of Respon Index)untuk mengeyahui miskonsepsi siswa dan angket untuk mengetahui respon siswa terhadap peta konsep. Setelah dilakukan pengolahan data, didapatkan hasil bahwa telah terjadi miskonsepsi siswa dalam kategori rendah pada materi sistem ekskresi dengan persentase rata-rata sebesar 18,8\%. Hasilmiskonsepsi tersebut berhubungan dengan peta konsep yang dibuat siswa.
\end{abstract}

Kata Kunci: Miskonsepsi, Peta Konsep, Sistem Ekskresi, Tes CRI

\section{PENDAHULUAN}

Belajar merupakan suatu upaya yang dilakukan seseorang untuk memperoleh perubahan dalam bentuk peningkatan kualitas tingkah laku, kecakapan, pemahaman, keterampilan, daya pikir dan pengetahuan melalui pengalaman. Pengalaman belajarsiswa menjadi hal utama untuk dapat menguasai dan memahami konsep sehinggadapat diimplementasikan dalam kehidupan sehari-hari. Pengetahuan yang diperoleh dari belajar tidak selalu sesuai dengan konsep, mengingat banyak faktor yang mempengaruhinya. Ketidaksesuaian tersebut dapat menyebabkan miskonsepsi.

Miskonsepsi atau salah konsep menunjuk pada suatu konsep yang tidak sesuai dengan pengertian ilmiah atau pengertian yang diterima para pakar dalam bidang itu 
(Suparno, 2013:4). Sejatinya miskonsepsi tidak boleh terjadi dalam dunia pendidikan, karena siswa yang telah mengalami miskonsepsi akan sulit memperbaiki konsep yang sebenarnya dan miskonsepsi juga dapat menganggu konsep-konsep yang baru.

Berdasarkan hasil wawancara dengan salah satu guru Biologi di suatu Sekolah Menengah Atas, miskonsepsi kerap kali terjadi pada Mata Pelajaran Biologi. Menurut guru tersebut, miskonsepsi dapat terjadi karena beberapa faktor. Faktor pertama, di dalam materi Biologi banyak terdapat konsep yang kompleks, bersifat abstrak, dan sulit untuk dipahami sehingga peluang untuk terjadinya miskonsepsi sangat besar. Faktor kedua, dalam proses pembelajaran sebagian guru kurang memperhatikan konsep awal yang dimiliki siswa sehingga untuk mempelajari konsep yang baru siswa tidak mampu mengembangkannya dan pada akhirnya menimbulkan miskonsepsi. Faktor ketiga yaitu kurangnya konsentrasi siswa saat kegiatan belajar mengajar berlangsung sehingga konsep yang diterima siswa menjadi terputus dan tidak utuh. Faktor terakhir yang menyebabkan miskonsepsi di sekolah tersebut adalah belum adanya cara untuk mengatasi miskonsepsi yang terjadi pada siswa.

Palmquist dan Finley menyatakan bahwa miskonsepsi tidak hanya dapat dialami oleh pemula tetapi juga seseorang yang telah ahli di bidangnya (Adrianto, Candramila, \& Ariyati, 2017). Miskonsepsi juga banyak dialami oleh guru (Nehm dan Schonfeld, 2007; Yates dan Marek, 2013), bahkan kadar miskonsepsinya sama dengan siswa (Bishop dan Anderson, 1990).

Menurut Kose (dalam Suhermiati, 2015:986) terdapat beberapa cara yang dapat digunakan untuk mengetahui pemahaman konsep dan miskonsepsi pada siswa yaitu berupa pertanyaan terbuka, two-tier diagnostik test, prediction-observation-explanation, wawancara mengenai suatu kejadian atau peristiwa, wawancara mengenai konsep, word association, menggambar dan peta konsep. Pada penelitian ini peneliti menggunakan penugasan peta konsep, tes berupa pilihan ganda beralasan disertai dengan Certainty of Respon Index (CRI). Penggunaan peta konsep dapat memfasilitasi siswa dalam proses pembelajaran menjadi bermakna karena berfungsi sebagai dasar untuk membantu mengorganisasikan pengetahuan konsep dan struktur kognitifnya.alam penelitian ini peta konsep digunakan sebagai tugas yang berfungsi untuk membantu siswa dalam memahami materi dan meminimalisir miskonsepsi.

Miskonsepsi juga dapat dilihat melalui Certainty of Respon Index (CRI). Certainty of Respon Index (CRI) merupakan teknik untuk mengetahui miskonsepsi seseorang dengan cara mengukur tingkat keyakinan atau kepastian seseorang dalam menjawab setiap 
pertanyaan yang diberikan. Certainty of Respon Index (CRI) dapat digunakan untuk mengetahui miskonsepsi pada beberapa materi dalam Mata Pelajaran Biologi.

Materi Biologi yang dipilih dalam penelitian ini adalah sistem ekskresi pada sub struktur dan fungsi sistem ekskresi pada manusia. Materi tersebut dianggap mempunyai tingkat kesukaran yang cukup tinggi terlihat dari konsep, proses, gejala dan peristiwa yang berkaitan didalamnya. Sehingga peluang untuk terjadinya miskonsepsi sangat besar.

Berdasarkan permasalahan yang telah dikemukakan, tampak bahwa penting dilakukan kajian mengenai miskonsepsi pada materi sistem ekskresi melalui penugasan peta konsep yang disertai dengan CRI. Oleh karena itu penelitian ini bertujuan untukmengetahui profil miskonsepsi siswa dalam materi sistem ekskresi melalui penugasan peta konsep.

\section{METODE PENELITIAN}

Jenis penelitian yang digunakan pada penelitian ini adalah metode penelitian kuantitatif deskriptif. Desain penelitian yang digunakan adalah Pre-Experimental Design dengan bentuk One-Shot Case Study.Adapun desain peneitiannya sebagai berikut:

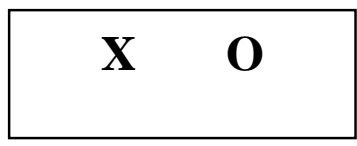

Keterangan :

$\mathrm{X}$ : Penugasan peta konsep

O : Observasi (hasil pengukuran)

Penelitian diawali dengan pemberian tugas membuat peta konsep tentang materi sistem eksresi yang sebelumnya sudah diajarkan oleh guru biologi di sekolah. Sebelum mengerjakan tugas peta konsep, siswa diajarkan membuat peta konsep yang benar. Peta konsep yang sudah dibuat, dikumpulkan dan dilanjutkan dengan pemberian soal postes.

Populasi dalam penelitian ini adalah seluruh kelas XI MIPA SMA Negeri 1 Sliyeg Indramayu yang terdiri dari empat kelas dengan jumlah siswa 145 orang. Sedangkan Sampel pada penelitian iniyaitu kelas XI MIPA 4 dengan jumlah siswa 37 orang.Teknik pengambilan sampel dilakukan dengan sampling purposive.Penarikan sampel ini dilakukan dengan pertimbangan berdasarkan rekomendasi guru dengan memilih kelas yang siswanya memiliki tingkat kemampuan yang tinggi.

Instrumen dalam penelitian ini berupa tes Pilihan Ganda (PG) beralasan disertai dengan CRI (Certainty of Respon Index)sebanyak 13 soal dan angket.Pembuatan angket bertujuan untuk mengetahui respon siswa terhadap penugasan peta konsep. Sedangkan tes PG berasalasan dengan CRI digunakan untuk mengungkap miskonsepsi siswa. 
Teknis analisis data berpedoman pada kombinasi jawaban yang diberikan (benar atau salah dengan nilai CRI rendah atau tinggi). Sehingga dapat diketahui persentase siswa miskonsepsi. Untuk menentukan kriteria tersebut dapat dianalisis dari Tabel 1. berikut ini :

\section{Tabel 1. Kriteria CRI}

\begin{tabular}{lll}
\hline Kriteria Jawaban & \multicolumn{1}{c}{ CRI Rendah } & \multicolumn{1}{c}{ CRI Tinggi } \\
\hline Jawaban Benar & Jawaban benar tetapi CRI rendah & Jawaban benar dan CRI tinggi \\
& berarti tidak tahu konsep & berarti menguasai konsep \\
& $($ Lucky guess $)$. & dengan baik (tahu konsep) \\
& & \\
\hline Jawaban Salah & Jawaban salah dan CRI rendah & Jawaban salah tapi CRI tinggi \\
& berarti tidak tahu konsep & berarti terjadi miskonsepsi \\
\hline
\end{tabular}

Sumber : Hasan (dalam Liliawati, 2009:4)

Untuk mencari persentase tingkat miskonsepsi digunakan rumus sebagai berikut :

$$
\mathrm{MK}=\frac{M K}{N} x 100 \%
$$

Keterangan :

MK = jumlah siswa miskonsepsi

$\mathrm{N} \quad=$ jumlah total siswa

Hasil persentase miskonsepsi dikelompokan berdasarkan kategori rendah, sedang dan tinggi, dapat dilihat pada Tabel 2.

Tabel 2. Persentase Tingkat Miskonsepsi

\begin{tabular}{ll}
\hline \multicolumn{1}{c}{ Persentase } & \multicolumn{1}{c}{ Kategori } \\
\hline $0-30 \%$ & Rendah \\
$31-60 \%$ & Sedang \\
$61-100 \%$ & Tinggi \\
\hline
\end{tabular}

Sumber : Suwarna (2013:4)

\section{HASIL DAN PEMBAHASAN}


Sebelum membahas lebih jauh mengenai miskonsepsi, berikut disajikan data hasil tes pilihan ganda beralasan disertai dengan Certainty of Respon Index (CRI) yang tercantum padaTabel 3.

Tabel 3. Persentase Tingkat Pemahaman Siswa

\begin{tabular}{c|c|c}
\hline \multicolumn{3}{c}{ Persentase Rata-Rata } \\
\hline Miskonsepsi & Tahu Konsep & $\begin{array}{c}\text { Tidak Tahu } \\
\text { konsep } \\
45,5 \%\end{array}$ \\
\hline
\end{tabular}

Berdasarkan data pada tabel 3. dapat dijelaskan bahwa tingkat pemahaman sebagian besar siswa kelas XI MIPA 4 SMA Negeri 1 Sliyeg berada pada kategori tidak tahu konsep $(45,5 \%)$ dan sebagian kecil lainnya berada pada kategori tahu konsep dengan rata-rata persentase sebesar $35,7 \%$. Terdapat banyak faktor yang mempengaruhi tingkat pemahaman siswa, misalnya metode pembelajaran, media pembelajaran, pengalaman belajar, dan tugas dalam pembelajaran. Pada penelitian ini hanya meninjau dari tugas dalam pembelajaran yang diberikan kepada siswa, yaitu pembuatan peta konsep.

Berdasarkan hasil angket hampir separuh siswa (42,2\%) berpendapat bahwa penugasan peta konsep dapat membantu mereka memahami materi. Hal ini berarti bahwa 57,8\% mengganggap peta konsep tidak dapat membantu mereka untuk memahami konsep sehingga masih banyak siswa yang tingkat pemahamannya berada pada level tidak tahu konsep. Berdasarkan hasil angket juga terlihat sebagian besar siswa $(55,8 \%)$ merasa termotivasi belajar dengan adanya penugasan peta konsep sehingga berdampak pada pemahaman konsep mereka. Hal ini dibuktikan dengan rata-rata persentase tingkat pemahaman pada kategori tahu konsep yang lebih besar dibandingkan dengan kategori miskonsepsi.

Miskonsepsi ialah suatu konsep yang tidak sesuai dengan pengertian ilmiah atau pengertian yang diterima para pakar dalam bidang itu (Suparno, 2013:4). Rata-rata miskonsepsi pada materi sistem ekskresi dalam penelitian ini ialah 18,8\%. Pengelompokan persentase miskonsepsi menurut Suwarna (2013:4) persentase 18,8\% termasuk ke dalam miskonsepsi tingkat rendah.

Lebih lanjut dijelaskan mengenai data miskonsepsi siswa yang tertuang dalam Tabel 4Siswayang dinyatakan miskonsepsi ialah mereka yang menjawab soal dengan benar tetapi alasannya salah atau menjawab soal dengan salah tetapi CRI tinggi. Data tersebut menunjukkan bahwa siswa mengalami miskonsepsi pada mata pelajaran Biologi yaitu tentang konsep Sistem Ekskresi. 
Tabel 4. Persentase Miskonsepsi Pada Setiap Indikator

\begin{tabular}{|c|c|c|c|}
\hline No & Indikator Soal & $\begin{array}{c}\text { Nomor } \\
\text { Soal }\end{array}$ & $\begin{array}{c}\text { Persentase } \\
\text { Miskonsepsi }\end{array}$ \\
\hline \multirow[t]{3}{*}{1.} & $\begin{array}{c}\text { Mengidentifikasi struktur sistem ekskresi } \\
\text { pada manusia }\end{array}$ & $1-2$ & 5,9 \\
\hline & & & 23,5 \\
\hline & Rata-Rata & & $14,7 \%$ \\
\hline \multirow[t]{8}{*}{2.} & Menjelaskan fungsi struktur sistem & & 20,6 \\
\hline & & & 26,5 \\
\hline & & $3-9$ & 50 \\
\hline & & & 20,6 \\
\hline & & & 5,9 \\
\hline & & & 0 \\
\hline & & & 8,8 \\
\hline & Rata-Rata & & $18,9 \%$ \\
\hline \multirow[t]{6}{*}{3.} & Menjelaskan mekanisme pembentukan & $10-13$ & 17,6 \\
\hline & urine & & 8,8 \\
\hline & & & 17,6 \\
\hline & & & 38,2 \\
\hline & Rata-Rata & & $20,5 \%$ \\
\hline & Rata-Rata Total & & $18,8 \%$ \\
\hline
\end{tabular}

Berdasarkan data yang terdapat pada Tabel 9. dapat dijelaskan bahwa dalam 13 soal yang diujikan terdapat tiga indikator. Indikator pertama yaitu mengidentifikasi struktur sistem ekskresi pada manusia yang mencakup dua nomor soal, dengan rata-rata miskonsepsi sebesar $14,7 \%$. Indikator kedua yaitu menjelaskan fungsi struktur sistem ekskresi yang terdiri dari tujuh nomor soal memperoleh rata-rata sebesar 18,9\%. Sedangkan miskonsepsi 
pada indikator ketiga yaitu menjelaskan mekanisme pembentukan urine yang mencakup empat nomor soal dengan rata-rata sebesar $20,5 \%$.

Jika Tabel 4 dinyatakan dalam bentuk grafik sehingga dapat melukiskan persentase siswa yang miskonsepsi dari setiap indikator soal, maka akan diperoleh hasil seperti gambar 3.

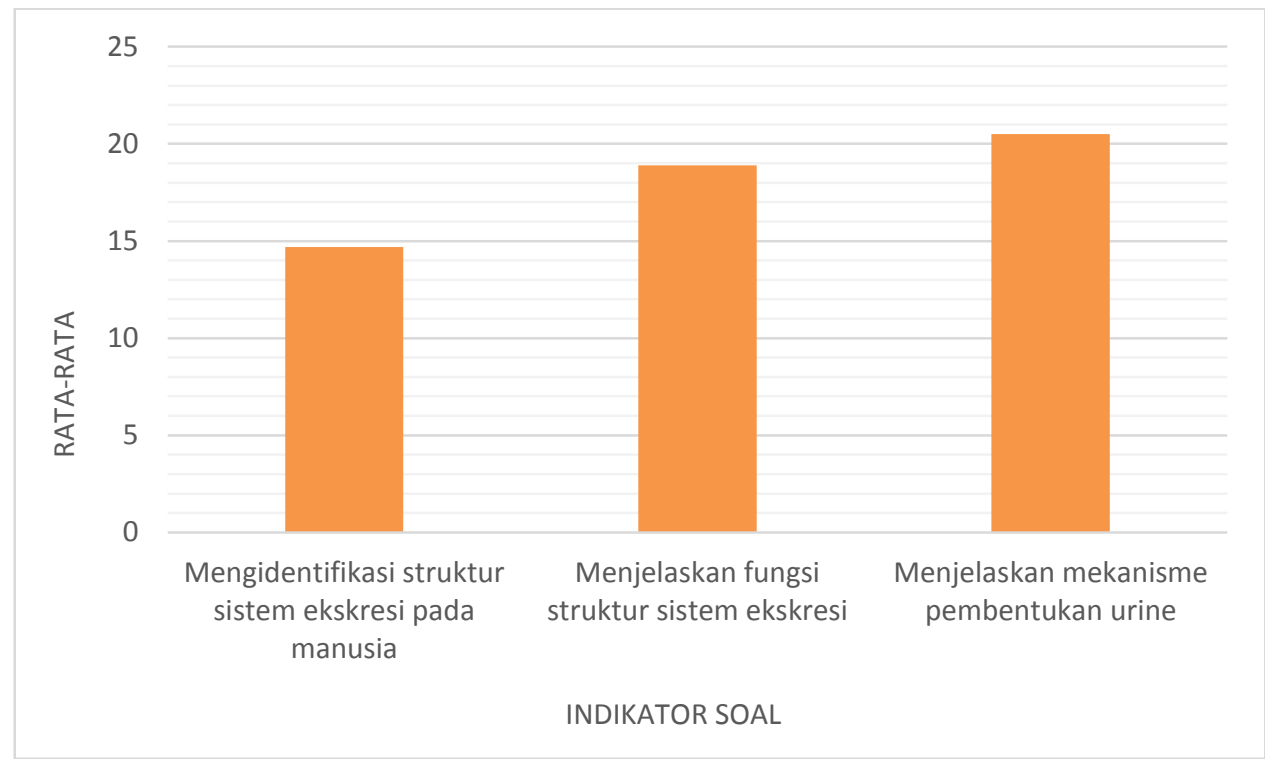

Gambar 1. Diagram Miskonsepsi Pada Setiap Indikator

Berdasarkan data pada tabel 4. dapat dilihat bahwa terdapat tiga indikator pembelajaran terdiri atas tiga belas soal. Miskonsepsi terjadi pada semua soal yang diujikan kecuali soal nomor delapan. Indikator pertama ialah mengidentifikasi struktur sistem ekskresi pada manusia mencakup dua nomor yaitu soal nomor satu dan dua. Pada soal nomor satu siswa diminta menentukan organ ekskresi yang mengeluarkan empedu. Sedangkan nomor dua, siswa diminta menunjukkan gambar bagian dari kulit yang menghasilkan keringat seperti pada gambar 2. Persentase miskonsepsi pada soal nomor satu sebesar 5,9\% denganjawaban siswa yaitu ginjal mengeluarkan empedu. Menurut konsep yang sebenarnya empedu diproduksi oleh hati dan dibentuk dalam sistem retikulo endothelium yang dialirkan ke empedu yang berperan dalam emulsifikasi dan absorbsi lemak(Setiadi, 2007:80).Dalam hal ini siswa dinyatakan miskonsepsi karena jawaban salah serta alasan yang diberikan tidak tepat, tetapi CRI tinggi. 


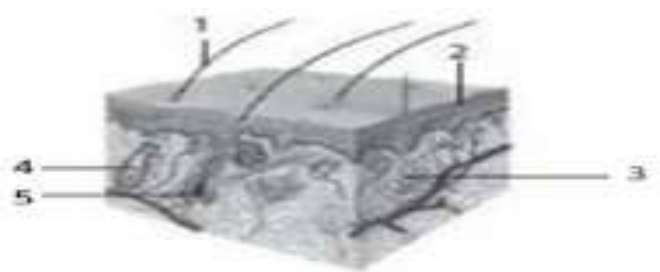

Gambar 2. Kulit Sumber : Biologi Media Centre

Sementara itu pada soal nomor dua telah terjadi miskonsepsi dengan persentase sebesar 23,5\%. Enam orang siswa menjawab bagian nomor 4 merupakan penghasil keringat, sedangkan dua orang siswa menjawab dengan jawaban yang benar tetapi alasan yang diberikan tidak tepat. Mereka menjawab bagian nomor 3 yang merupakan penghasil keringat. Namun, alasan yang diberikan ialah "kelenjar minyak dan kelenjar keringat samasama muncul pada rambut kulit”. Dari alasan di atas dapat diketahui bahwa siswa terbalik dalam mengidentifikasi kelenjar minyak dan kelenjar keringat. Oleh karena itu siswa dinyatakan miskonsepsi karena jawaban benar serta alasan yang diberikan tidak tepat, tetapi CRI tinggi.

Jika dikaitkan dengan hasil penugasan peta konsep dari siswa yang mengalami miskonsepsi pada soal nomor satu, bagian hati memang kurang dibahas secara detail, sehingga dapat mempengaruhi pemahaman siswa mengenai soal yang membahas tentang hati. Sedangkan hasil penugasan peta konsep yang membahas nomor 2 mayoritas semua siswa membuat peta konsep hanya berbentuk tulisan sehingga ketika soal yang diberikan dalam bentuk gambar, sebagian siswa merasa bingung dan terjadi miskonsepsi.

Indikator kedua ialah menjelaskan fungsi struktur sistem ekskresi dengan mencakup tujuh nomor yaitu soal nomor tiga sampai sembilan. Soal nomor tiga ialah mengidentifikasi kelainan ginjal pada hasil tes urine. Setelah dilakukan analisis, miskonsepsi terjadi pada tujuh orang siswa dengan persentase sebesar 20,6\%. Lima orang siswa menjawab adanya glukosa pada urin disebabkan oleh proses filtrasi yang tidak berjalan dengan baik, sedangkan dua siswa lainnya menjawab penyebab adanya glukosa ialah kelainan pada proses augmentasi. Konsep yang sebenarnya yaitu zat terlarut yang berharga termasuk glukosa, garam-garam tertentu, vitamin, hormon, dan asam amino direabsorpsi melalui transport aktif (Campbell, 2005). Ketika glukosa terdapat pada urin maka telah terjadi kerusakan pada proses reabsorpsi. Dalam hal ini siswa dinyatakan miskonsepsi karena jawaban salah serta alasan yang diberikan tidak tepat, tetapi CRI tinggi. Jika dikaitkan dengan hasil penugasan peta konsep, dari tujuh orang siswa yang miskonsepsi dua diantaranya membahas tentang 
komponen-komponen urin pada peta konsepnya. Sedangkan lima orang sisanya tidak membahas tentang komponen-komponen urin.

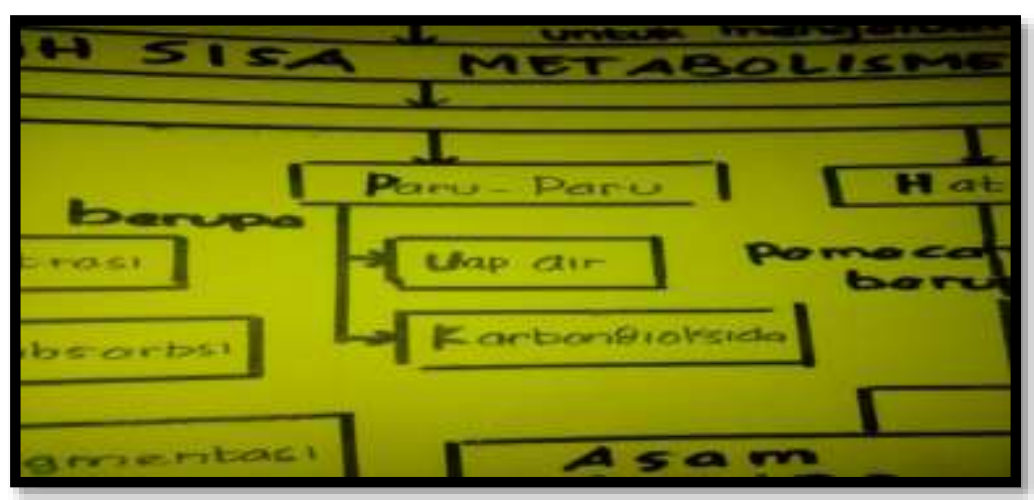

Gambar 3. Peta Konsep Paru-Paru

Pada soal nomor empat dengan indikator yang sama, siswa diminta untuk menentukan organ ekskresi yang mengeluarkan karbondioksida dalam bentuk uap air. Tabel 4 menunjukkan bahwa pada soal tersebut dengan persentase sebesar 26,5\% miskonsepsi terjadi pada sembilan orang siswa. Jawaban kesembilan siswa tersebut ialah "kulit mengubah karbon dioksida dalam bentuk uap air dan dikeluarkan melalui pori-pori kulit yang disebut dengan keringat". Melihat dari jawaban siswa, dapat diketahui bahwa siswa menganggap keringat merupakan hasil dari perubahan karbondioksida menjadi uap air. Sedangkan menurut konsep yang sebenarnya paru-paru merupakan organ berbentuk piramid seperti spons dan berisi udara (Sloane, 2003:269).Dalam hal ini siswa dinyatakan miskonsepsi karena jawaban salah serta alasan yang diberikan tidak tepat, tetapi CRI tinggi. Jika dilihat dari hasil penugasan peta konsep, empat dari sembilan siswa di dalam peta konsepnya membahas tentang uap air yang dikeluarkan oleh paru-paru seperti pada Gambar 3. Artinya penugasan peta konsep tidak dapat membuat siswa memahami konsep dengan benar. Sebagaimana hasil angket menunjukkan lebih dari separuh siswa yang mengganggap peta konsep tidak membantu mereka dalam memahami konsep. 


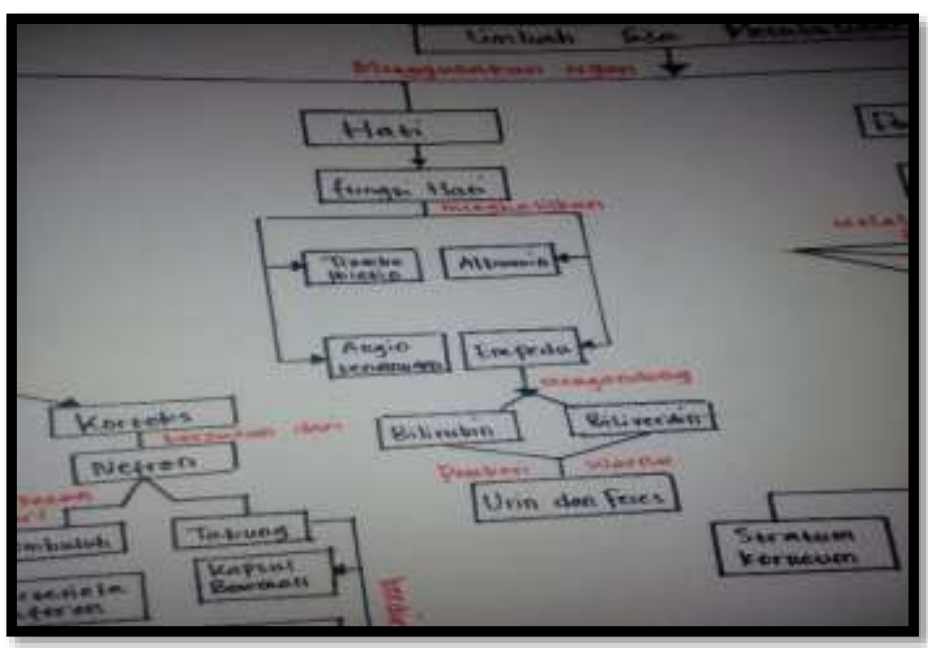

Gambar 4. Peta Konsep Hati

Soal nomor lima yaitu menentukan zat yang tidak dihasilkan oleh hati. Setelah dianalisis miskonsepsi tertinggi terjadi pada soal nomor lima tepatnya sebanyak tujuh belas orang siswa dengan persentase sebesar 50\%. Jika dilihat dari indikatornya, jelas bahwa indikator kedua lebih rumit jika dibandingkan dengan indikator pertama sehingga miskonsepsi tertinggi berada pada indikator ini. Ditinjau dari hasil peta konsep yang dibuat oleh siswa, enam dari tujuh belas siswa yang mengalami miskonsepsi dalam peta konsepnya membahas tentang zat-zat yang dihasilkan oleh hati seperti pada Gambar 4. Sehingga dapat dikatakan bahwa penugasan peta konsep tidak dapat membuat siswa memahami konsep dengan baik. Sementara itu sebagian siswa yang miskonsepsi menyatakan bahwa hati tidak menghasilkan bilirubin dan sebagian lainnya menjawab bahwa urea tidak dihasilkan di hati, melainkan dihasilkan oleh ginjal. Konsep yang sebenarnya hati memiliki fungsi untuk menghasilkan empedu, sedangkan empedu mengandung bilirubin dan biliverdin. Selain empedu, hati juga menghasilkan enzim glikogenik yang mengubah glukosa menjadi glikogen. Selain itu hati mengurai protein dari sel-sel tubuh dan sel darah merah yang rusak dan hasil penguraian protein menghasilkan urea dari asam amino berlebih dan sisa nitrogen (Setiadi, 2007:80).Melihat dari alasan jawaban siswa dapat diketahui bahwa siswa dinyatakan miskonsepsi karena jawaban salah serta alasan yang diberikan tidak tepat, tetapi CRI tinggi.

Selanjutnya pada soal nomor enam masih dengan indikator yang sama, siswa diminta untuk menentukan akibat dari kerusakan fungsi hati. Setelah dianalisis miskonsepsi terjadi pada tujuh orang siswa dengan persentase sebesar 20,6\%. Lima orang siswa menjawab kerusakan fungsi hati pada seseorang akan mengakibatkan tubuh mengalami kelebihan $\mathrm{NH}_{3}$, sedangkan dua orang siswa lainnya mengatakan bahwa hati adalah organ tubuh yang 
menghasilkan zat toksik yang tidak menyebabkan kerusakan pada hati. Melihat alasan dari jawaban siswa tersebut diketahui bahwa siswa mengalami miskonsepsi, karena konsep yang sebenarnya adalah jika hati mengalami kerusakan maka hati tidak bisa menjalankan tugasnya seperti menghancurkan zat racun, sehingga racun yang berada di dalam tubuh akan menumpuk. Dari penjelasan di atas dapat disimpulkan bahwa siswa mengalami miskonsepsi dilihat dari jawaban dan alasan yang diberikan tidak tepat, tetapi CRI tinggi. Jika ditinjau dari peta konsep yang dibuat oleh siswa, empat diantaranya membahas fungsi dari hati. Namun, karena soal nomor enam merupakan soal aplikasi maka masih terdapat siswa yang terkecoh dengan jawabannya.

Pada soal nomor tujuh, siswa diminta untuk menentukan akibat dari kulit yang kekurangan melanin. Sloane (2003:86) berpendapat bahwapada rentang yang terbatas, melanin melindungi kulit dari sinar ultraviolet matahari yang merusak. Peningkatan produksi melanin berlangsung jika terpajan sinar matahari, sehingga sesorang yang tidak memiliki melanin yang cukup tidak tahan dengan terik matahari. Hasil analisis miskonsepsi pada nomor tujuh, terdapat dua orang siswa yang miskonsepsi dengan persentase sebesar 5,9\%. Dua orang siswa tersebut menyatakan bahwa "kurangnya melanin pada kulit dapat menyebabkan seseorang tidak tahan dengan udara dingin". Berdasarkan alasan dan jawaban siswa dapat diketahui bahwa siswa dinyatakan miskonsepsi karena jawaban salah serta alasan yang diberikan tidak tepat, tetapi CRI tinggi. Ditinjau dari hasil penugasan peta konsep, dua orang siswa yang mengalami miskonsepsi tersebut membahas tentang melanin. Pada nomor ini soal yang digunakan berjenis aplikatif sehingga dapat mengecoh siswa.

Pada soal nomor delapan tidak ada satu pun siswa yang mengalami miskonsepsi. Hal ini dikarenakan tingkat kesukaran soal yang rendah. Tingkat kesukaran soal yang rendah dapat dibuktikan berdasarkan tingkat pemahaman terbanyak pada soal ini yaitu tahu konsep dengan jumlah siswa dua puluh tujuh, sedangkan tingkat pemahaman tidak tahu konsep hanya berjumlah tujuh siswa.

Pada soal nomor sembilan, siswa diminta untuk menentukan penyebab kulit gelap orang Dayak. Berdasarkan hasil analisis pada soal nomor sembilan, telah terjadi miskonsepsi pada tiga orang siswa dengan persentase sebesar $8,8 \%$. Ketiga siswa tersebut dinyatakan miskonsepsi karena mengatakan bahwa suku Dayak kurang mengkonsumsi makanan yang mengandung protein sehingga suku Dayak memiliki kulit yang gelap. Jika dilihat dari alasan ketiga siswa tersebut dapat disimpulkan bahwa siswa mengira bahwa melanin merupakan suatu zat dari luar yang dapat mempengaruhi pigmen kulit seseorang. Melihat alasan dan jawaban siswa dapat diketahui bahwa siswa dinyatakan miskonsepsi karena jawaban salah 
serta alasan yang diberikan tidak tepat, tetapi CRI tinggi. Jika ditinjau dari hasil peta konsep yang dibuat oleh siswa, ketiganya membahas tentang melanin. Sehingga dapat disimpulkan bahwa penugasan peta konsep tidak dapat membuat siswa lebih memahami materi.

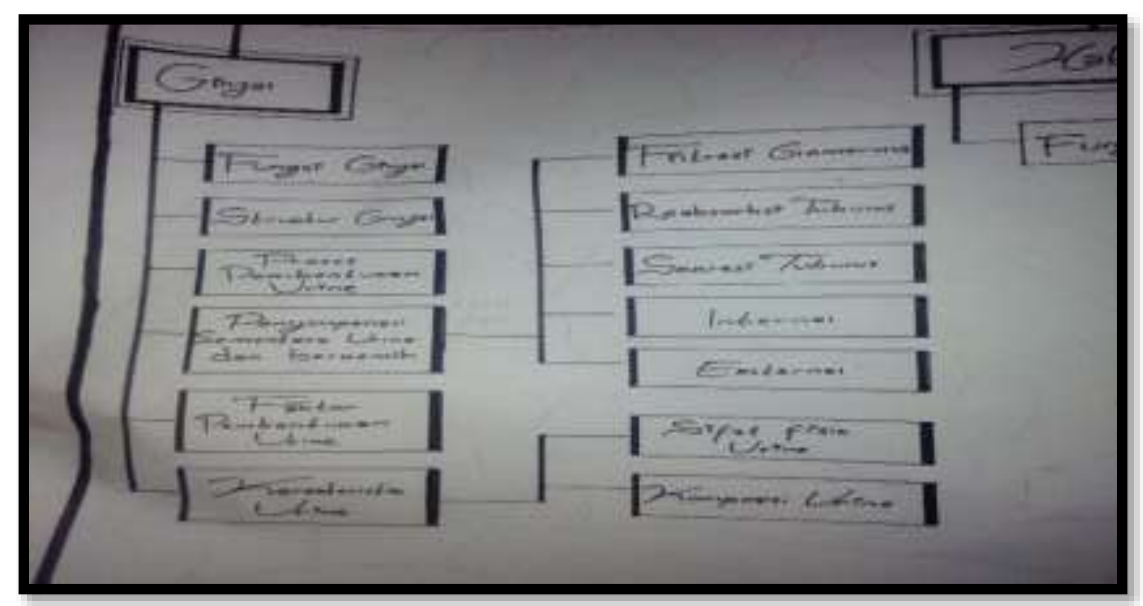

Gambar 5. Peta Konsep Ginjal

Indikator ketiga yaitu menjelaskan mekanisme pembentukan urin dengan mencakup empat nomor yaitu soal nomor sepuluh sampai tiga belas. Pada soal nomor sepuluh siswa diminta untuk menentukan faktor yang mempengaruhi proses pembentukan urin. Sedangkan nomor sebelas, siswa diminta untuk megidentifikasi kelainan melalui hasil tes urine. Berdasarkan hasil anlisis pada soal nomor sepuluh telah terjadi miskonsepsi pada enam orang siswa dengan persentase sebesar $17,6 \%$.Enam orang siswa tersebut menyatakan bahwa alkohol akan meningkatkan sekresi ADH dan akibatnya volume urin juga akan meningkat. Menurut konsep yang sebenarnya Anti Diuretik Hormon (ADH) berfungsi meningkatkan permeabilitas kontortus distal dan tubulus pengumpul terhadap air sehingga mengakibatkan terjadinya reabsorpsi air dan volume urin sedikit (Sloane, 2003:324). Jadi ketika seseorang mengkonsumsi alkohol, urin yang akan dikeluarkan akan banyakkarena ADH tidak dapat bekerja dengan baik. Melihat dari alasan jawaban siswa dapat diketahui bahwa siswa dinyatakan miskonsepsi karena jawaban salah serta alasan yang diberikan tidak tepat, tetapi CRI tinggi.

Sementara itu pada soal nomor sebelas miskonsepsi terjadi pada tiga orang siswa dengan persentase sebesar $8,8 \%$. Ketiga orang siswa tersebut menyatakan bahwa glomerulus menyaring protein. Jika dilihat dari alasannya secara tidak langsung ketiga siswa tersebut menyatakan bahwa protein dapat disaring pada proses filtrasi yang bertempat di glomerulus. Menurut Irnaningytas (2016:332)urin mengandung protein karena terjadi kesalahan pada 
proses filtrasi yang terjadi di glomerulus. Zat-zat besar seperti protein dan sel darah merah seharusnya tidak bisa disaring oleh glomerulus, tetapi karena glomerulusmengalami kerusakan maka protein ikut masuk dan tercampur dalam urin. Melihat dari alasan jawaban siswa maka siswa dinyatakan miskonsepsi karena jawaban salah serta alasan yang diberikan tidak tepat, tetapi CRI tinggi.

Jika ditinjau dari hasil peta konsep dari siswa yang mengalami miskonsepsi pada nomor sepuluh, empat dari enam orang yang mengalami miskonsepsi dalam peta konsepnya memang tidak membahas mengenai faktor yang mempengaruhi proses pembentukan urin. Sedangkan hasil penugasan peta konsep dari ketiga siswa yang mengalami miskonsepsi pada nomor sebelas dalam peta konsepnya membahas tentang komponen-komponen urin.Sehingga dapat disimpulkan bahwa penugasan peta konsep tidak dapat membantu siswa dalam memahami materi.

Pada soal nomor dua belas siswa diminta untuk mengidentifikasi hasil urin sekunder. Setelah dianalisis telah terjadi miskonsepsi pada enam orang siswa dengan persentase sebesar $17,6 \%$. Ditinjau dari penugasan peta konsep yang dibuat oleh siswa, enam orang siswa yang mengalami miskonsepsi tidak membahas tentang komponen urin sekunder pada peta konsepnya.Empat orang siswa yang mengalami miskonsepsi menyatakan bahwa urin sekunder tidak menghasilkan protein, glukosa, dan urea. Sedangkan dua orang siswa lainnya menyatakan urea tidak ikut tersaring pada proses filtrasi sehingga urea bukan komponen dari urin sekunder. Sedangkan menurut konsep yang sebenarnya protein merupakan zat besar yang tidak dapat difiltrasi sehingga protein tidak ada dalam komponen urin (Sloane, 203).

Melihat dari alasan jawaban siswa maka dapat disimpulkan bahwa siswa tersebut mengalami miskonsepsi karena jawaban salah serta alasan yang diberikan tidak tepat, tetapi CRI tinggi.

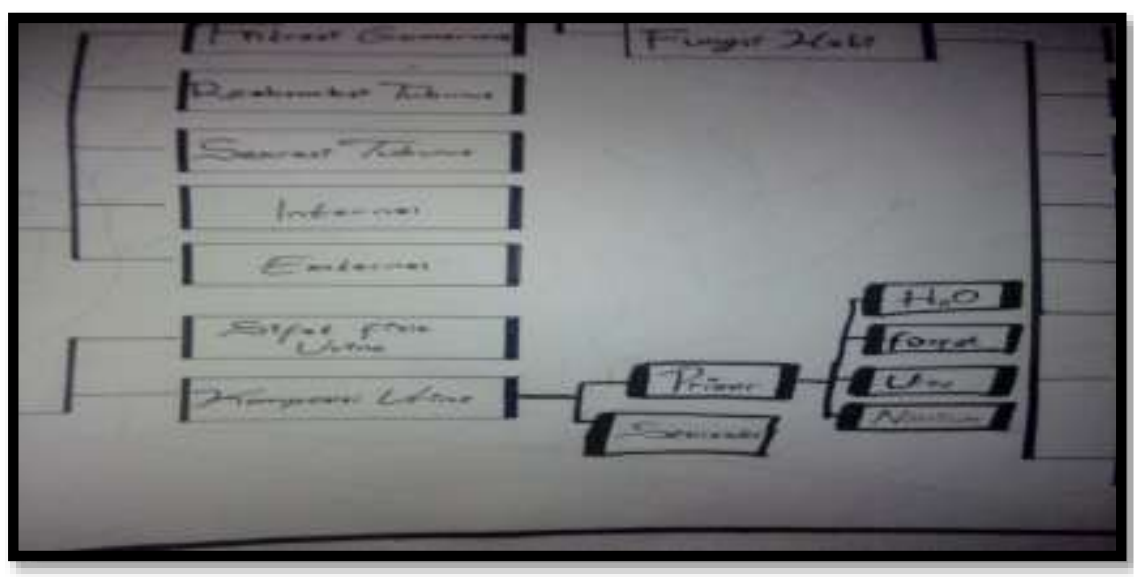

Gambar 6. Peta Konsep Komponen Urin Primer 
Pada soal terakhir yaitu nomor tiga belas dengan indikator yang sama, siswa diminta untuk menentukan komponen urin primer. Setelah dianalisis telah terjadi miskonsepsi pada tiga belas orang siswa dengan persentase sebesar $38,2 \%$. Ketiga belas orang siswa menyatakan bahwa $\mathrm{H}_{2} \mathrm{O}$ dan sel darah merah termasuk dalam komponen urin primer. Menurut pendapat Irnaningtyas (2016:333) sel darah merah tidak dapat difiltrasi sehingga tidak ada dalam komponen urin primer.Melihat dari alasan dan jawaban siswa maka dapat disimpulkan bahwa siswa tersebut mengalami miskonsepsi karena jawaban salah serta alasan yang diberikan tidak tepat, tetapi CRI tinggi.Jika ditinjau dari hasil peta konsep yang dibuat oleh siswa, tujuh dari tiga belas orang siswa yang mengalami miskonsepsi membahas tentang komponen urin primer pada peta konsepnya seperti pada Gambar 6.Sehingga dapat disimpulkan bahwa penugasan peta konsep tidak dapat membantu siswa dalam memahami materi.

Berdasarkan pemaparan di atas, miskonsepsi hampir ada di semua soal. Namun demikian yang terjadi pada siswa kelas XI MIPA 4 SMA Negeri 1 Sliyeg berada pada kategori rendah. Hal ini tidak luput dari peran penugasan peta konsep diawal penelitian. Tugas pembuatan peta konsep yang diberikan bersifat individu. Artinya siswa tidak diperkenankan untuk membuat peta konsep yang sama dengan temannya. Hal ini sejalan dengan hasil persentase indikator kerjasama yang rendah yaitu 41,6\%. Selain itu penugasan peta konsep juga dapat menambah rasa tanggung jawab siswa. Hal ini didukung dengan respon tertinggi siswa pada indikator tanggungjawab yaitu sebesar 76,6\% yang berarti hampir seluruh siswa bertanggungjawab dengan tugas yang diberikan. Respon tertinggi pada indikator tanggungjawab berpengaruh pada indikator ketelitian, karena hampir separuh siswa $(46,7 \%)$ teliti dalam membuat tugas peta konsep. Maksudnya ketika hampir seluruh siswa dapat bertanggungjawab atas tugas peta konsep yang diberikan, maka siswa akan teliti dalam memilih konsep-konsep penting pada materi, teliti dalam memilih kata hubung yang pas untuk menghubungkan antar konsep sehingga peta konsep dapat dipahami dengan baik.Meskipun tidak semua konsep dapat diingat dengan baik setidaknya dengan diterapkannya penugasan peta konsep di awal penelitian membuat siswa mengingat beberapa konsep yang telah dipelajari dalam pembuatan peta konsep dan diharapkan dapat mengurangi peluang miskonsepsi. MenurutSuparno (2013:29) salah satu sebab terjadinya miskonsepsi pada siswa berasal dari sudut filsafat kontruktivisme yaitupengetahuan dibentuk (dikonstruk) oleh siswa sendiri dalam kontak dengan lingkungan, tantangan, dan bahan yang dipelajari. Oleh karena siswa yang mengonstruksikan sendiri pengetahuannya, maka tidak mustahil dapat terjadi kesalahan dalam mengkonstruksi karena tidak semua siswa 
dapat mengartikan dengan benar maksud konsep-konsep dari buku yang dijadikan sumber pembuatan peta konsep sehingga terdapat beberapa siswa yang terindikasi mengalami miskonsepsi.

Miskonsepsi pada siswa juga terjadi karena kesalahan dalam pembuatan peta konsep. Ditinjau dari hasil penugasan peta konsep yang dibuat siswa, terdapat beberapa siswa yang tidak memperhatikan cara membuat peta konsep sesuai dengan arahan peneliti yang merujuk padalangkah-langkah pembuatan peta konsep menurut Arends(dalam Trianto, 2017:186). Karena dalam pembuatan peta konsep tidak sesuai dengan langkah-langkah pembuatan peta konsep menurut Arends (dalam Trianto, 2017:186) yaitu a) memilih suatu bahan bacaan; b) menentukan konsep-konsep penting yang terdapat dalam bacaan; c) mengurutkan konsep dari yang inklusif ke yang kurang inklusif; d) menyusun konsep tersebut dalam suatu bagan, konsep yang inklusif diletakkan dibagian atas atau puncak peta, lalu dihubungkan dengan kata penghubung, misalnya "terdiri atas","menggunakan", dan lain-lain, maka membuat siswa sulit untuk memahami materi melalui peta konsep yang dibuatnya, sehingga terjadi miskonsepsi. Kesalahan dalam pembuatan peta konsep dapat diidentifikasi karena ketika peneliti menjelaskan cara membuat peta konsep, konsentrasi siswa terganggu karena jam pelajaran hampir selesai, sehingga hasil peta konsep tidak sesuai dengan harapan peneliti.

\section{KESIMPULAN}

Berdasarkan hasil penelitian dan pembahasan dapat disimpulkan bahwa telah terjadi miskonsepsi siswa dalam kategori rendah pada materi sistem ekskresi melalui penugasan peta konsep.

\section{DAFTAR PUSTAKA}

Adrianto, O. M., Candramila, W., \& Ariyati, E. 2017. Analisis Konsepsi dan Miskonsepsi Siswa kelas XII IPA SMA Don Boso Sanggau pada Materi Evolusi. Jurnal Pendidikan Biologi UNTAN.

Bishop, B. A. \& Anderson, C. W. 1986. Student Conception of Natural Selection and Its Role in Evolution. The Institute for Research on Teaching: Michigan State University. 
Nehm, R. H, \& Schonfeld, IS. 2007. Does Increasing Biology Teacher Knowledge of Evolution and the Nature of Science Lead to Greater Preference for the Teaching of Evolution in Schools? Journal of Science Teacher Education. 18: 699-723.

Campbell N.A, J.B. Reece \& L.G. Mitchcell. 2005. Biologi Edisi ke-5. Terj. Dari Biologi. $5^{\text {th }}$ ed. Oleh Manalu, W. Jakarta: Erlangga.

Liliawati, Winny, Dkk. 2009. Identifikasi Miskonsepsi Materi IPBA Di SMA dengan Menggunakan CRI (Certainly Of Respons Index) Dalam Upaya Perbaikan Urutan Pemberian Materi IPBA Pada KTSP. EPrints@UNY. 5(7): 159-168.

Setiadi. 2007. Anatomi Dan Fisiologi Manusia. Yogyakarta: Graha Ilmu.

Sloane, Ethel. 2003. Anatomi Dan Fisiologi Untuk Pemula. Jakarta: EGC.

Suhermiati, Ita. 2015. Analisis Miskonsepsi Siswa Pada Materi Pokok Sintesis Protein Ditinjau Dari Hasil Belajar Biologi Siswa. Jurnal BIOEDU. Vol 4 No.3 985-990.

Suparno, Paul. 2013. Miskonsepsi Dan Perubahan Konsep Dalam Pendidikan Fisika. Jakarta: Grasindo.

Suwarna, Permana, I. 2014. Analisis Miskonsepsi Siswa SMA Kelas X Pada Mata Pelajaran Fisika Melalui CRI (Certainty Of Response Index) Termodifikasi. Instituional Repository UIN Syarif Hidayatullah Jakarta. 1-15.

Trianto. 2017. Mendesain Model Pembelajaran Inovatif, Progresif, dan Kontekstual. Jakarta: Kencana.

Suprijono, Agus. 2013. Cooperative learning teori \& aplikasi PAILKEM. Jakarta: Pustaka Belajar. 